\title{
Lysozyme increases bactericidal activity of ceragenin CSA-13 against Bacillus subtilis
}

\section{Lizozym nasila bakteriobójcza aktywność cerageniny CSA-13 w stosunku do Bacillus subtilis}

\author{
Bonita Durnaśs ${ }^{1}$ Krzysztof Fiedoruk², Mateusz Cieśluk³, Piotr Deptuła³, Grzegorz Król'1, Ewelina Piktel³, \\ Paul B. Savage ${ }^{4}$, Robert Bucki ${ }^{3}$ \\ 'Department of Microbiology and Immunology, Faculty of Medicine and Health Sciences, Jan Kochanowski University, Kielce, Poland \\ Head of the Department: Prof. Robert Bucki, MD, PhD \\ 2Department of Microbiology, Medical University of Bialystok, Bialystok, Poland \\ Head of the Department: Prof. Robert Bucki, MD, PhD \\ ${ }^{3}$ Department of Microbiological and Nanobiomedical Engineering, Medical University of Białystok, Poland \\ Head of the Department: Prof. Robert Bucki, MD, PhD \\ ${ }^{4}$ Department of Chemistry and Biochemistry, Brigham Young University, Provo, USA \\ Head of the Department: Prof. Greg Burton MD, PhD
}

Medical Studies/Studia Medyczne 2019; 35 (1): 1-9 DOI: https://doi.org/10.5114/ms.2019.83847

Key words: synergism, Bacillus subtilis, antimicrobial peptides, lysozyme, ceragenins.

Stowa kluczowe: synergizm, Bacillus subtilis, peptydy przeciwbakteryjne, lizozym, cerageniny.

\begin{abstract}
Introduction: Bacillus subtilis and other opportunistic bacilli are responsible for infrequent but serious infections such as post-surgery and post-traumatic endophthalmitis. Lysozyme is a natural protein found in various body fluids, exerting direct antibacterial activity and involved in modulation of the immune response in the site of inflammation. Ceragenins (CSAs) are cationic lipids based on cholic acid structure. CSA-13, the best-characterised molecule of its family, is distinct due to its broad-spectrum of antibacterial activity against aerobic and anaerobic Gram-positive and Gram-negative bacteria, as well as multidrug-resistant strains of fungi, parasites, and some viruses.

Aim of the research: To assess whether a combination of lysozyme (the antibacterial enzyme present in various human body fluids) and CSA-13 (a new synthetic mimic of natural antimicrobial peptides) will display higher bactericidal activity against $B$. subtilis in comparison to their activity alone.

Material and methods: The antimicrobial activities of lysozyme, CSA-13, and their combination were determined using a killing assay, and changes in bacterial cell morphology upon exposure to these antimicrobials were visualised by atomic force microscopy (AFM). In addition, interactions between the tested compounds were analysed using reductions in bacterial counts and determination of synergistic effects.

Conclusions: The effects of combined treatment involving lysozyme and CSA-13 against B. subtilis indicate synergistic antibacterial activity that might be used in the development of new methods to combat infections caused by this genus of bacteria.

\section{Streszczenie}

Wprowadzenie: Bacillus subtilis oraz inne oportunistyczne laseczki odpowiadają za infekcje bakteryjne występujące ze względnie niską częstością, ale skutkujące poważnymi powikłaniami zdrowotnymi. Do tej grupy zalicza się przede wszystkim pooperacyjne i pourazowe zapalenie wnętrza gałki ocznej. Lizozym to białko pochodzenia naturalnego, które jest obecne w wielu płynach ustrojowych. Wykazuje on aktywność przeciwbakteryjną i jest zaangażowany w modulację odpowiedzi układu odpornościowego w trakcie infekcji oraz stanu zapalnego. Cerageniny (CSAs) sa kationowymi pochodnymi kwasu cholowego. Wykazano, że CSA-13, najlepiej poznany przedstawiciel tej klasy związków, charakteryzuje się znaczną aktywnością przeciwdrobnoustrojową w stosunku do tlenowych i beztlenowych bakterii Gram-dodatnich i Gram-ujemnych oraz lekoopornych szczepów grzybów, pasożytów oraz niektórych wirusów.

Cel pracy: Ocena, czy kombinacja lizozymu (enzymu przeciwbakteryjnego obecnego w różnych płynach ustrojowych człowieka) i CSA-13 (nowego syntetycznego analogu naturalnych peptydów przeciwdrobnoustrojowych) wykazuje wyższą aktywność bakteriobójczą przeciw B. subtilis niż stosowanie ich pojedynczo.

Materiał i metody: Aktywność przeciwbakteryjną lizozymu, CSA-13 oraz ich kombinacji oceniono metodą killing assay. Zmiany w morfologii komórek bakteryjnych pod wpływem analizowanych związków badano przy użyciu mikroskopii sił atomowych (AFM). Wzajemne interakcje pomiędzy tymi czynnikami analizowano poprzez obliczenie redukcji liczby kolonii bakteryjnych oraz tzw. wartości efektu synergistycznego.

Wnioski: Nasilenie aktywności przeciwbakteryjnej przeciwko B. subtilis obserwowane w przypadku kombinacji lizozymu oraz CSA-13 może zostać wykorzystane jako nowy sposób walki z infekcjami powodowanymi przez te bakterie.
\end{abstract}




\section{Introduction}

Members of the genus Bacillus are Gram-positive, spore-forming, rod-shaped bacteria, widely distributed in natural environments, especially in soil, food products, air, and water. In addition, some species are members of human and animal intestinal microbiota [1]. Despite routine cleaning procedures Bacillus strains are also found in hospital settings in various reservoirs such as ventilation equipment, linen, medical devices, gloves, hands of medical staff, or alcohol-based hand disinfectant solutions, hence they are often regarded as environmental contaminants [2]. Although only Bacillus anthracis is considered a strict pathogen in this group, several other species, in particular B. cereus, B. subtilis, B. licheniformis, and $B$. thuringiensis, may cause various opportunistic infections. With the development of modern medicine, many immunocompromised individuals are able to live longer, and the clinical significance of these opportunistic bacilli is constantly growing $[3,4]$. In general, eye infections, such as post-traumatic or post-surgery endophthalmitis, are among the most frequently described conditions. However, other conditions such as traumatic and surgical wound infections, bacteraemia, central venous catheter-linked infections, endocarditis, meningitis, brain abscesses, osteomyelitis, pulmonary infections, or neonatal infections are also commonly reported. The presence of intravascular devices, dialysis, alcoholism, trauma, intravenous drug use, haematological malignancies, and premature birth are important predisposing factors for such infections. Finally, B. cereus is a wellrecognised enteropathogen, causing toxin-mediated food-borne acute gastroenteritis [5-12].

Lysozyme is a natural protein and a key player in innate immunity. It is found in tissues, body fluids, and cells exposed to the environment or involved in bacterial clearance (e.g. mucosal surfaces of respiratory, intestinal, urogenital tracts, tears, saliva, serum, breast milk, and urine as well as phagocytes, including macrophages, neutrophils, and dendritic cells). Generally, its two main tasks are (i) direct antibacterial activity and (ii) modulation of immune response in the site of inflammation $[13,14]$.

Ceragenins (CSAs) are cationic lipids synthesised using the structural base of cholic acid, and CSA-13 is the best-characterised molecule of its family $[15,16]$. They mimic the amphiphilic character of natural antibacterial peptides such as cathelicidin LL-37, and are described by broad-spectrum antibacterial activity against aerobic and anaerobic Gram-positive and Gram-negative bacteria, as well as multidrugresistant strains of fungi, parasites, and some viruses [17-20]. Furthermore, ceragenins are effective against microorganisms in both planktonic and biofilm form [21].

\section{Aim of the research}

In the present paper, our intention was to study the antibacterial activity of a combination of lysozyme and CSA-13 against a model bacterium B. subtilis.

\section{Material and methods \\ Antimicrobial testing}

Bactericidal activities of lysozyme from chicken egg white and ceragenin CSA-13 (synthesised as previously reported [22]), against the reference strain of $B$. subtilis ATCC 6051, were evaluated using a colony formingunit (CFU) assay, as described previously [23]. Briefly, $B$. subtilis bacteria were grown overnight on LuriaBertani (LB) agar plates (Difco, Sparks, MD) at $37^{\circ} \mathrm{C}$ to reach a mid-log phase of growth, resuspended in $\mathrm{PBS}$, and brought to $10^{8} \mathrm{CFU} / \mathrm{ml}$ (which corresponds to optical density of 0.5 at $600 \mathrm{~nm}$ ). Next, the bacterial suspension was adjusted to $10^{5} \mathrm{CFU} / \mathrm{ml}$ and treated with different concentrations of tested agents $(0-50 \mathrm{U} / \mathrm{ml}$ of lysozyme, and/or $0-5 \mu \mathrm{M}$ of CSA-13). After $1 \mathrm{~h}$ of incubation at $37^{\circ} \mathrm{C}$ the plates were transferred to ice and suspensions were diluted 10- to 1000 -fold in PBS. Then, $10 \mu \mathrm{l}$ aliquots were spotted on agar plates for overnight culture at $37^{\circ} \mathrm{C}$, after which CFUs were determined. The CFUs $(\mathrm{CFU} / \mathrm{ml})$ of the individual samples were determined from the dilution factor and were used to calculate the percentage of bacterial outgrowth.

\section{Evaluation of the antibacterial activity of CSA-13/lysozyme combinations}

To evaluate possible synergy between ceragenin CSA-13 and lysozyme, microbial outgrowth reduction and synergistic effect values were calculated as presented previously [24]. A mutual antimicrobial effect of the analysed compounds was calculated as follows: synergistic effect value $=A-(B+C)$, where $A$ is the reduction of colonies from combined CSA-13/lysozyme treatment, $\mathrm{B}$ is the reduction from CSA-13 treatment alone, and $\mathrm{C}$ is the reduction from lysozyme treatment alone. A synergistic effect value $>0$ indicates beneficial and synergistic interaction between tested agents, and values $<0$ suggest decreased benefit of combining treatment. A synergistic effect value of 0 indicates that there is no synergistic effect of combining the individual treatments.

\section{Atomic force microscopy (AFM) analysis}

To visualise the effects of CSA-13 and lysozyme combinations on bacteria, topography images of treated bacterial cells were recorded using atomic force microscopy, as a qualitative assessment of antibioticmediated cell destruction. In all AFM-based experiments $B$. subtilis cells were resuspended in distilled water $\left(\mathrm{OD}_{600} \sim 0.1\right)$, and incubated with $0.5-1 \mu \mathrm{M}$ of CSA-13, $5 \mathrm{U} / \mathrm{ml}$ of lysozyme or CSA-13 and lysozyme 

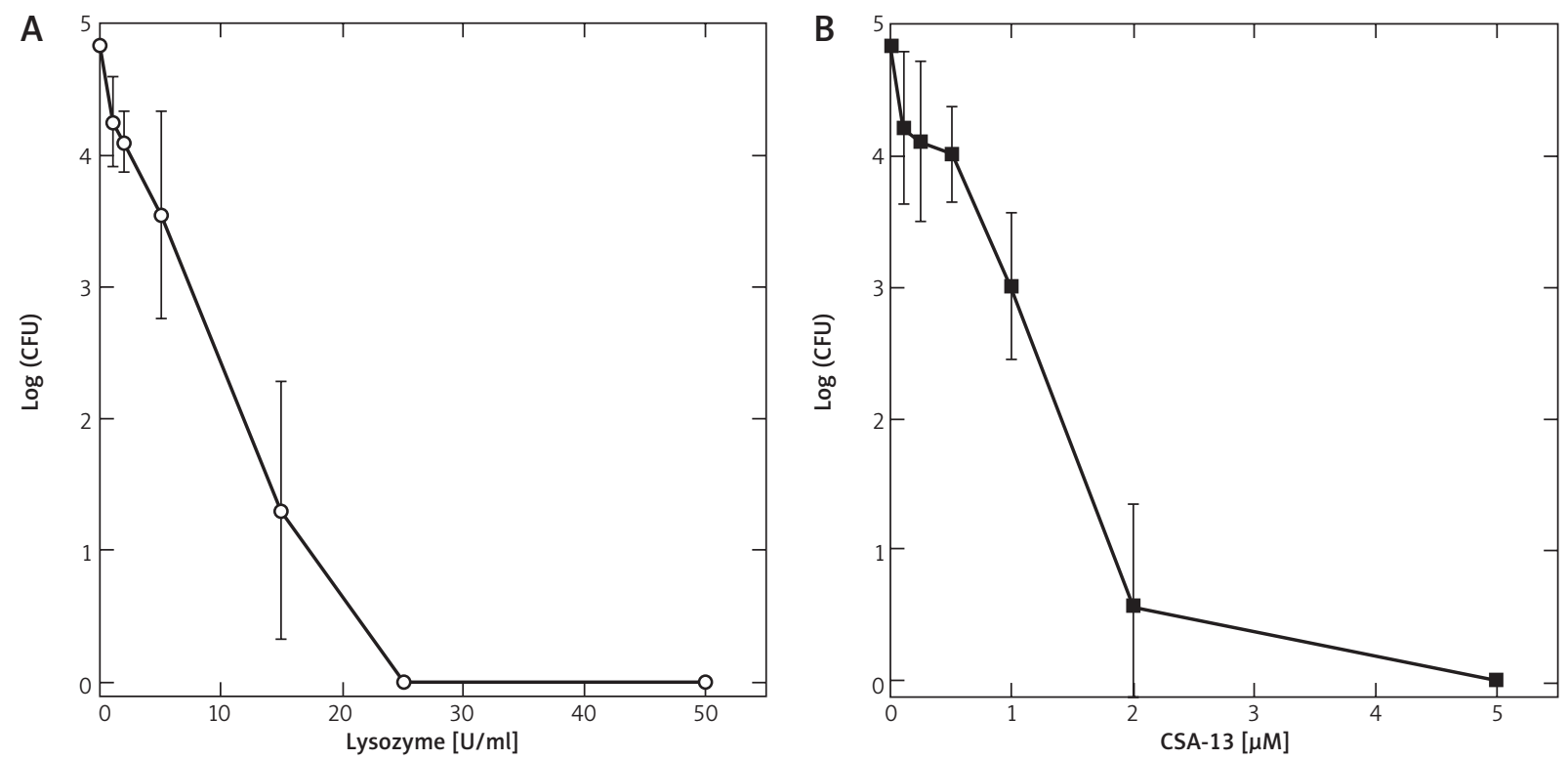

Figure 1. Bactericidal activity of lysozyme (A) and CSA-13 (B) against Bacillus subtilis. Error bars represent standard deviations from three to six measurements

in combinations (the concentrations were estimated based on the maximum numerical synergistic value, see results), at $37^{\circ} \mathrm{C}$ for $60 \mathrm{~min}$. Then, $200 \mu \mathrm{l}$ of bacterial samples were transferred to a mica surface precoated with 5\% (3-aminopropyl)triethoxysilane (APTES) in water. Bacteria attachment to functionalised mica was achieved during 20-min incubation. Images were collected using a Nano Wizard 4 BioScience AFM (JPK Instruments, Germany) working in Contact Mode and Quantitative Imaging (QI) Mode. App Nano NITRA-TALL-V-G triangular pyramid shaped tips with a nominal spring constant equal to $0.24 \mathrm{~N} / \mathrm{m}$ were employed. Initially, the tip was brought into contact with the surface of a bacterial cell until a given deflection of the cantilever was reached. The scanning was then started with a constant velocity of $3 \mu \mathrm{m} / \mathrm{s}$. Three signals were recorded simultaneously while scanning the sample surface: topography, vertical deflection of the cantilever, and error signal, with a resolution of 128 pixels per line. Topography images serve as a qualitative assessment, while vertical deflection and error signal uncover surface features with better clarity. Due to the high adhesion between the AFM tip and damaged cells after incubation and lateral forces during contact mode scanning, a force curve-based imaging mode was used (QI mode) with the resolution of 128 pixels per line, using the same cantilever.

\section{Results}

\section{Lysozyme and ceragenin CSA-13 exert antibacterial activity against $B$. subtilis ATCC 6051}

As shown in Figure $1 \mathrm{~A}$ and B, a decline in the survival of $B$. subtilis cells after incubation with various

concentrations of lysozyme and CSA-13 was observed, indicating that both agents display activity against B. subtilis. Complete inhibition of bacterial growth occurred when $25 \mathrm{U} / \mathrm{ml}$ of lysozyme and $5 \mu \mathrm{M}$ of CSA-13 were applied.

\section{Lysozyme exerts synergistic effects with ceragenin CSA-13 against $B$. subtilis}

The decrease of bacterial survival and colony forming capability upon combined treatment with ceragenin CSA-13 and lysozyme is presented in Figure 2 and Table 1. As shown in Figure 2, the combination of natural and synthetic-based agents significantly reduced the number of bacterial colonies upon 1 -h incubation. The reduction of $B$. subtilis colonies was $0.17 \pm 0.22$ to $4.48 \pm 0.06 \log \mathrm{CFU} / \mathrm{ml}$, depending on the concentrations of tested agents. It was shown that an increase in CSA-13 concentration resulted in a decrease in bacterial viability, and this effect was further strengthened by relatively low doses of lysozyme, which suggest synergistic interactions between these compounds. The maximum numerical synergistic value was $1.38 \log \mathrm{CFU} / \mathrm{ml}$ after combined treatment with CSA-13 and lysozyme in doses of $1 \mu \mathrm{M}$ and $5 \mathrm{U} / \mathrm{ml}$, respectively. Accordingly, a significant decrease in $B$. subtilis viability by $4.48 \pm 0.06 \mathrm{log}$ $\mathrm{CFU} / \mathrm{ml}$ was observed (Figure $2 \mathrm{D}$, Table 1 ). In contrast, treatment of B. subtilis with CSA-13 and lysozyme alone led to a decrease of bacterial outgrowth by $1.82 \pm 0.02$ and $1.28 \pm 0.246 \log \mathrm{CFU} / \mathrm{ml}$, respectively. Such lysozyme-mediated improved bactericidal activity of ceragenin was also observed when lysozyme was co-applied with lower doses of CSA-13, i.e. $0.25 \mu \mathrm{M}$ and $0.5 \mu \mathrm{M}$ (Figures $2 \mathrm{~B}$ and $\mathrm{C}$ ), and the numerical difference was 0.63 to $0.88 \log \mathrm{CFU} / \mathrm{ml}$. 


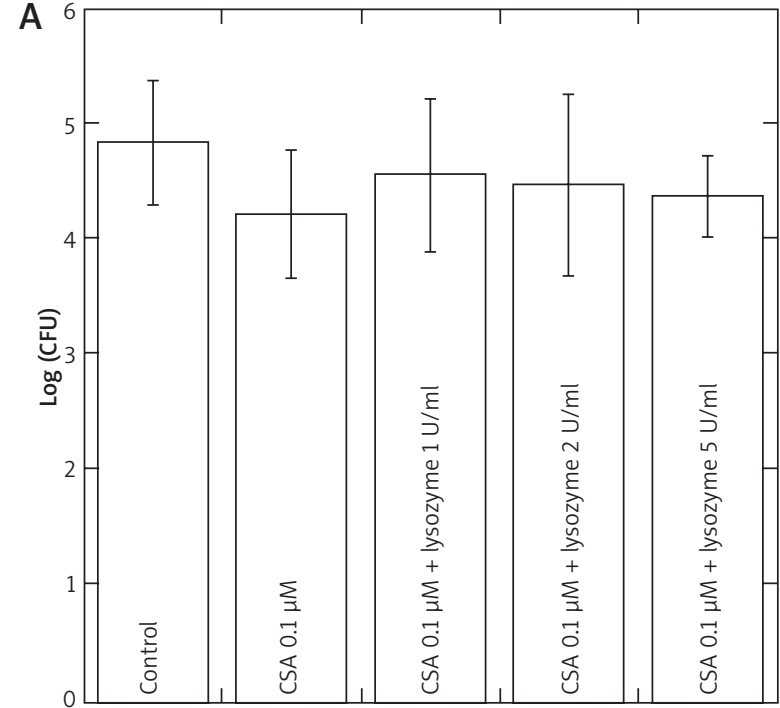

Samples

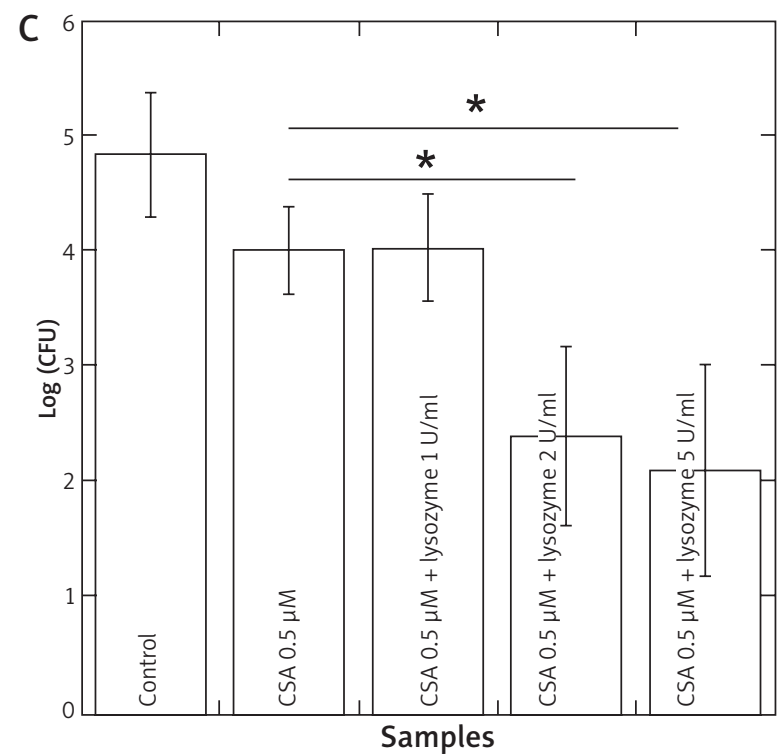

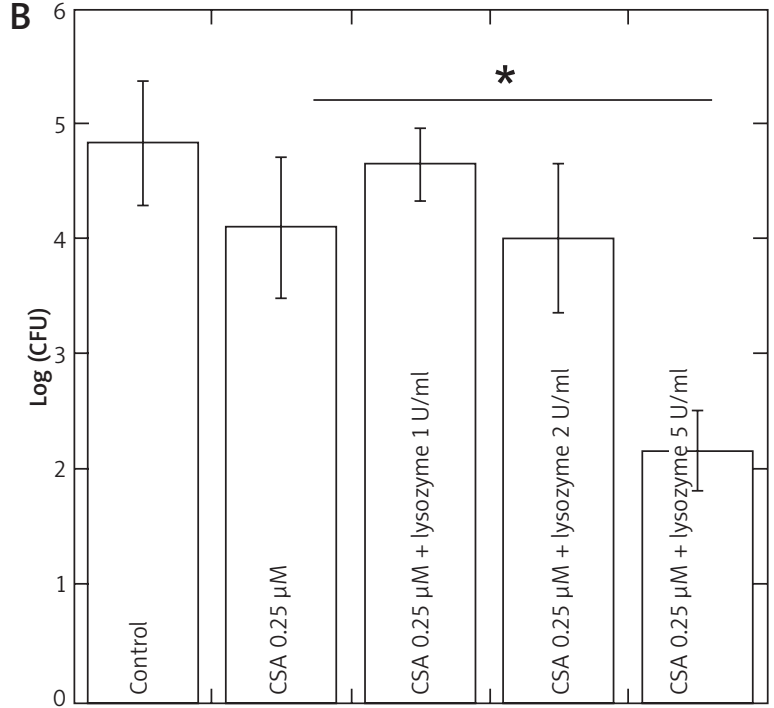

Samples

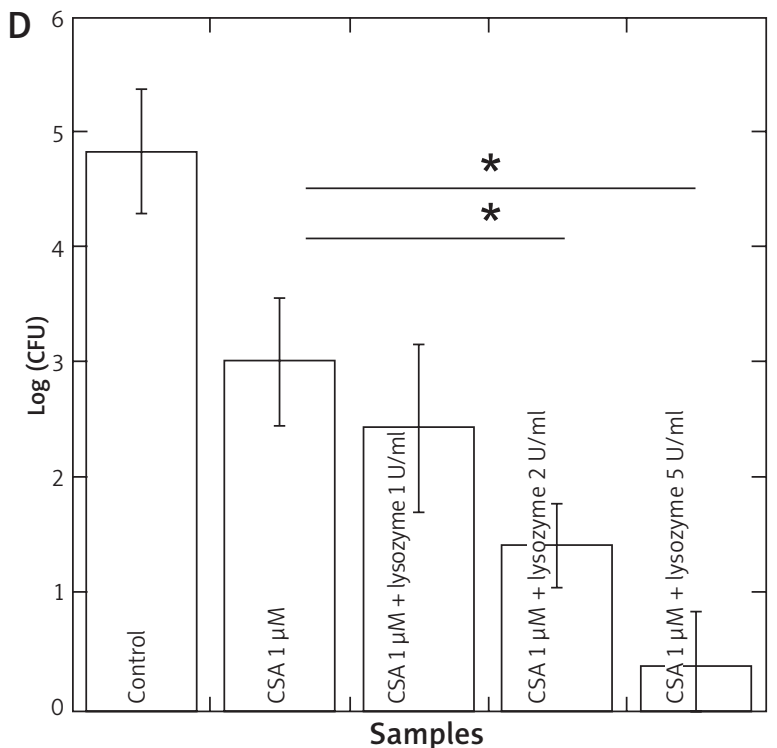

Figure 2. Improvement of antimicrobial activity of CSA-13 by co-treatment with varied concentrations of lysozyme. Panels demonstrate the decrease of Bacillus subtilis outgrowth upon treatment with $0.1 \mu \mathrm{M}$ (A), $0.25 \mu \mathrm{M}$ (B), $0.5 \mu \mathrm{M}$ (C), and 1 MM CSA-13 (D) in combination with lysozyme in doses of 1, 2, and $5 \mathrm{U} / \mathrm{ml}$. Error bars represent standard deviations from three to six measurements

*The statistical significance $(p<0.05)$ when compared to untreated control samples.

These results strongly suggest that combined treatments with CSA-13 and lysozyme result in a greater microbial reduction than the treatments applied individually, and this effect is particularly prominent with higher doses of both agents.

\section{Morphology of B. subtilis cells subjected to lysozyme/CSA-13 treatment}

As indicated in Figure 3, B. subtilis cells exposed to lysozyme and CSA-13 revealed changes in surface morphology that indicate bacterial membrane dam- age. The extent of membrane blebbing and the presence of cell fragments and aggregations increased when combined treatment was applied. Overall, these changes were very similar to the membrane damage observed previously for Pseudomonas aeruginosa PA01 and LESB58 strains [25].

\section{Discussion}

The growing level of resistance to antimicrobials among pathogens involved in human infections requires the development of novel therapeutic options, 
Table 1. Reduction and synergistic effect values recorded for bacterial samples treated with CSA-13 and lysozyme in various combinations

\begin{tabular}{|lccc|}
\hline Parameter & Reduction value & Synergistic effect value & Interpretation \\
CSA-13 $0.1 \mu \mathrm{M}$ & $0.62 \pm 0.02$ & $\mathrm{n} / \mathrm{a}$ & $\mathrm{n} / \mathrm{a}$ \\
CSA-13 $0.25 \mu \mathrm{M}$ & $0.72 \pm 0.07$ & $\mathrm{n} / \mathrm{a}$ & $\mathrm{n} / \mathrm{a}$ \\
CSA-13 $0.5 \mu \mathrm{M}$ & $0.82 \pm 0.17$ & $\mathrm{n} / \mathrm{a}$ & $\mathrm{n} / \mathrm{a}$ \\
CSA-13 $1 \mu \mathrm{M}$ & $1.82 \pm 0.02$ & $\mathrm{n} / \mathrm{a}$ & $\mathrm{n} / \mathrm{a}$ \\
Lysozyme $1 \mathrm{U} / \mathrm{ml}$ & $0.58 \pm 0.195$ & $\mathrm{n} / \mathrm{a}$ & $\mathrm{n} / \mathrm{a}$ \\
Lysozyme $2 \mathrm{U} / \mathrm{ml}$ & $0.73 \pm 0.306$ & $\mathrm{n} / \mathrm{a}$ & $\mathrm{n} / \mathrm{a}$ \\
Lysozyme $5 \mathrm{U} / \mathrm{ml}$ & $1.28 \pm 0.246$ & $\mathrm{n} / \mathrm{a}$ & Not beneficial \\
CSA-13 $0.1 \mu \mathrm{M}+$ lysozyme $1 \mathrm{U} / \mathrm{ml}$ & $0.28 \pm 0.13$ & -0.92 & Not beneficial \\
CSA-13 $0.1 \mu \mathrm{M}+$ lysozyme $2 \mathrm{U} / \mathrm{ml}$ & -0.98 & Not beneficial \\
CSA-13 $0.1 \mu \mathrm{M}+$ lysozyme $5 \mathrm{U} / \mathrm{ml}$ & $0.37 \pm 0.248$ & -1.43 & Not beneficial \\
CSA-13 $0.25 \mu \mathrm{M}$ + lysozyme $1 \mathrm{U} / \mathrm{ml}$ & $0.47 \pm 0.19$ & -1.13 & Not beneficial \\
CSA-13 $0.25 \mu \mathrm{M}+$ lysozyme $2 \mathrm{U} / \mathrm{ml}$ & $0.17 \pm 0.22$ & -0.65 & Synergistic \\
CSA-13 $0.25 \mu \mathrm{M}+$ lysozyme $5 \mathrm{U} / \mathrm{ml}$ & $0.81 \pm 0.11$ & +0.66 & Not beneficial \\
CSA-13 $0.5 \mu \mathrm{M}+$ lysozyme $1 \mathrm{U} / \mathrm{ml}$ & $2.66 \pm 0.2$ & -0.6 & Synergistic \\
CSA-13 $0.5 \mu \mathrm{M}+$ lysozyme $2 \mathrm{U} / \mathrm{ml}$ & $0.8 \pm 0.07$ & +0.88 & Synergistic \\
CSA-13 $0.5 \mu \mathrm{M}+$ lysozyme $5 \mathrm{U} / \mathrm{ml}$ & $2.43 \pm 0.25$ & +0.63 & Indifferent \\
CSA-13 $1 \mu \mathrm{M}+$ lysozyme $1 \mathrm{U} / \mathrm{ml}$ & $2.73 \pm 0.37$ & 0 & Synergistic \\
CSA-13 $1 \mu \mathrm{M}+$ lysozyme $2 \mathrm{U} / \mathrm{ml}$ & $2.4 \pm 0.2$ & +0.88 & Synergistic \\
CSA-13 $1 \mu \mathrm{M}+$ lysozyme $5 \mathrm{U} / \mathrm{ml}$ & $3.43 \pm 0.18$ & +1.38 & \\
\hline
\end{tabular}

Untreated
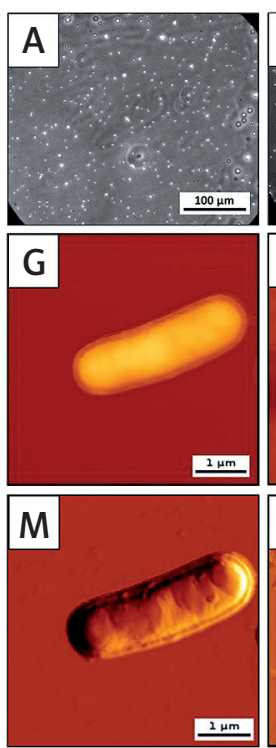

CSA-13 $0.5 \mu \mathrm{M}$
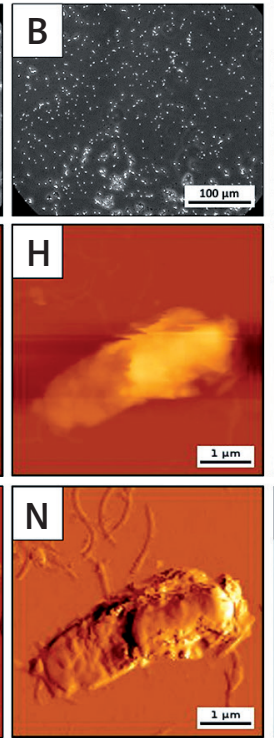

CSA-13 $1 \mu \mathrm{M}$
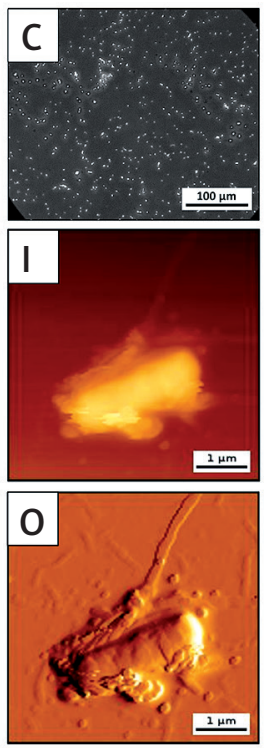

Lysozyme $5 \mathrm{U} / \mathrm{ml}$
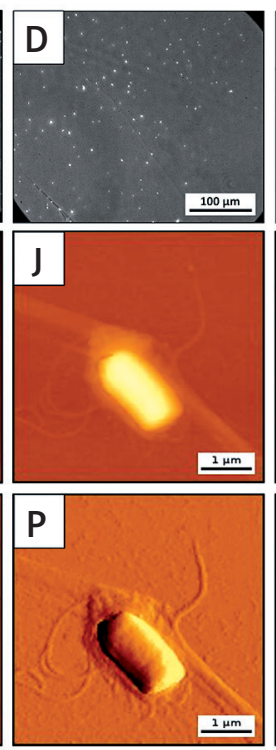

CSA-13 $0.5 \mu \mathrm{M}+$ lysozyme $5 \mathrm{U} / \mathrm{ml}$

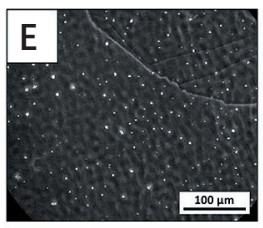

CSA-13 $1 \mu \mathrm{M}+$ lysozyme $5 \mathrm{U} / \mathrm{ml}$
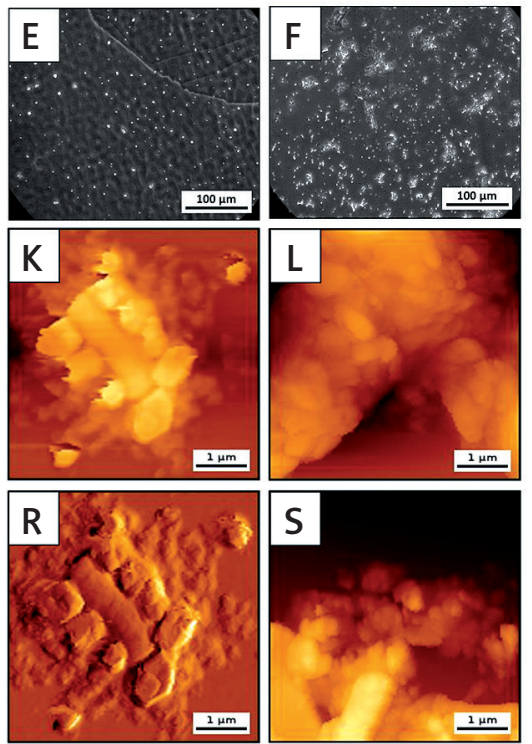

S

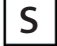

Figure 3. Atomic force microscopy measurements of untreated (A, G, M) Bacillus subtilis bacteria and incubated with $0.5 \mu \mathrm{M}$ CSA-13 (B, H, N), $1 \mu \mathrm{M}$ CSA-13 (C, I, O), and $5 \mathrm{U} / \mathrm{ml}$ of lysozyme (D, J, P) and with $0.5 \mu \mathrm{M}$ or $1 \mu \mathrm{M}$ CSA-13 in combination with $5 \mathrm{U} / \mathrm{ml}$ of lysozyme $(\mathrm{E}, \mathrm{K}, \mathrm{R}$ and $\mathrm{F}, \mathrm{L}, \mathrm{S}$, respectively). A-F -present optical images collected during AFM measurements, G-K, M-R - demonstrate topography images and error signal recorded using AFM. L, S - images obtained from treated bacterial cells using QI mode. Scale bar: $1 \mu \mathrm{m}$. Representative results from one experiment are shown 
as well as searching for new antibiotics. Combining antimicrobials is a promising approach, not only for improving antimicrobial therapy but also for controlling resistance developing through natural evolution. When drugs are combined, the synergistic, antagonistic, or additive effects on bacterial cells may be observed. In general, the mode of action of the drugs determines the interaction that occurs between them [26].

One possible approach for use of antimicrobial combinations for medical benefit is the analysis of the role of natural peptides present on the skin, mucosal surfaces, and in body fluids [27], in combination with exogenous antimicrobials [28]. In our study, we examined a combination of ceragenin CSA-13 and lysozyme against B. subtilis ATCC 6051, a model organism for other species of bacilli. Apart from the ability to produce virulence factors, there are no significant differences in susceptibility to antimicrobials among various species of Bacillus, so our results can be related to other members of genus Bacillus.Notably, manyGram-positivebacilli, otherthan B. anthracis (the causative agent of the deadly disease anthrax), are well-recognised opportunistic pathogens responsible for systemic diseases in immunocompromised patients as well as local, post-surgical, and post-traumatic infections [29]. For instance, B. cereus, due to secretion of toxins detrimental to ocular tissue, rapid intraocular migration, and the ability to stimulate a strong inflammatory response, is described as an aetiological agent of dangerous, sometimes fulminant infective endophthalmitis, which demands early and aggressive therapy [30]. In addition, similarly to other pathogens, multidrug or even extensive drugresistant strains of bacilli, especially among $B$. cereus isolates, have been reported [31, 32].

As reported previously, ceragenins have well-documented antibacterial properties. They act against a broad spectrum of Gram-positive and Gram-negative bacteria, including multidrug-resistant organisms [33]. The activity of CSA-13 against $B$. subtilis, both vegetative cells and spores, has also been described [23]. Our data confirm this observation with Bacillus vegetative forms and demonstrate that the bacterial killing activity of CSA-13 is enhanced by lysozyme, as supported by AFM imagining.

In general, synergy can be observed when two antimicrobials associate with various targets in bacterial cells. The primary mode of ceragenin action against bacteria is concentration-dependent cell membrane depolarisation causing cellular dysfunction. Electrostatic interactions between cationic ceragenin and negatively-charged bacterial membrane molecules such as phosphatidylglycerol and LPS effectively kills bacteria, and this mechanism of action is unlikely to induce resistance [34]. Lysozyme can act through two different mechanisms. The primary mechanism leads to cell wall instability and subsequently to cell death as the result of hydrolysis of the $\beta$ - $(1,4)$-glycosidic bond between $\mathrm{N}$-acetylmuramic acid and $\mathrm{N}$-acetylglucosamine in the peptidoglycan (PG). The secondary mode, less important in Gram-positive bacteria, is independent of PG hydrolysis. Lysozyme, being highly cationic, can insert into negatively charged bacterial membranes and form pores [14]. So, the explanation for the synergistic interaction between CSA-13 and lysozyme against Gram-positive bacteria lies in the different modes of action of CSA-13 that targets the cell membrane and lysozyme that targets the cell wall peptidoglycan. In this combination one antimicrobial increases the permeability of the cell's external barrier to another. Earlier in vitro studies also demonstrated that the activity of CSA-13 against Pseudomonas aeruginosa and Helicobacter pylori was augmented by host-secreted antimicrobial agents (including lysozyme), although it is known that lysozyme activity against Gram-negative bacteria is weak. In this situation, lysozyme acts by the membrane-dependent mechanism, so an additive but not synergistic effect was observed [35]. This study confirms that enhanced antibacterial activity of CSA-13 against bacteria might be expected at sites where lysozyme is present. Despite the reports on different biological features of hen egg white lysozyme (used in this study) and human lysozyme, we suggest that the same phenomenon might occur in human hosts [36]. It is established that in the site of infection exogenous antibiotics act in the presence of various natural host antibacterial products, and their combined action can influence the final antimicrobial effect. Such complex interactions of antimicrobial peptides are found in airway surface liquid, which include lysozyme, lactoferrin, secretory leukocyte protease inhibitor (SLPI), human b-defensins, and LL-37. Singh et al. [37] observed synergistic or additive effects of tobramycin with these natural defences against Escherichia coli. Notably, a triple combination of lysozyme, lactoferrin, and SLPI displayed even greater synergy with tobramycin than did pairs of antibacterial factors. Moreover, the study revealed that antimicrobial potency in body sites, where multiple antimicrobial compounds are present, can be increased by their interactions. However, some inhibitory factors, such as increased salt concentrations, may diminish these synergistic effects and inhibit local mucosal defences [37]. The enhanced activity of exogenous antibiotics by endogenous defences, other than lysozyme, present on skin and mucosal surfaces, has also been demonstrated in related studies. In one of these, the synergy between cathelicidin LL-37 and conventional, bactericidal antibiotics (amoxicillin with clavulanic acid and amikacin) was described [38]. On the other hand, the combination of LL-37 and bacteriostatic tetracycline or erythromycin re- 
sulted in antagonism [38]. It is worth underlining that the mucosal concentration of LL-37 increases in the course of infection [27]. Interestingly, in patients with atopic dermatitis decreased expression of antimicrobial peptides is observed [28]. As far as the effectiveness of antimicrobial treatment is concerned, the interactions between various exogenous as well as endogenous antibacterial compounds at the site of infection seem to play a key role in overall antimicrobial activity, especially in local infections. Therefore, the combination of lysozyme and ceragenins examined in our study might be a promising form of supplementary therapy in ocular infections caused by Bacillus. The combination could also be considered in the development of products for wound healing for topical applications. Ceragenins, with their: (i) strong antimicrobial activity against a variety of microorganisms, even Bacillus spores, (ii) ability to inhibit biofilm formation, (iii) biological activity in body fluids, (iv) good safety profile, and (v) anti-inflammatory properties, could be excellent candidates for potential use also in such infections as endophthalmitis [39]. Endophthalmitis following ocular trauma can be caused by a wide range of bacteria and fungi, including multidrug-resistant organisms. Because endophthalmitis is a serious and devastating condition, an early broad-spectrum antibiotic therapy should be introduced before results from susceptibility testing are available [40]. Antibiotics can be administered by topical, systemic, or intravitreal route [41]. CSA-13, thanks to its wide spectrum of activity and synergy with lysozyme that is naturally present in tears but also can be administrated as an exogenous drug, seems to be a reasonable option for ocular infections. Another important value is the synergistic effects of CSA-13 in combination with conventional antibiotics against selected clinical resistant strains, as demonstrated in previous studies [42, 43]. In our study we used lysozyme isolated from chicken egg white. Even though chicken and human lysozyme display similarities concerning the primary sequence and molecular weight, they differ in terms of enzymatic activity. Because human lysozyme is approximately threefold more active than chicken lysozyme we might assume that its lower concentration will be sufficient to observe synergy when combined with CSA-13 [36, 44].

\section{Conclusions}

Our data demonstrate and highlight the synergy of lysozyme and CSA-13 and confirm the concept that activity of exogenous antimicrobials is enhanced by host factors. A better description of synergy between natural substances found in inflammatory sites and locally administrated antimicrobials may be a potential direction of research for novel strategies for the treatment of topical infections.

\section{Acknowledgments}

This work was supported by a program of the Minister of Science and Higher Education under the name "Regional Initiative of Excellence" in 2019-2022, project number: 024/RID/2018/19, financing amount: $11,999,000.00$ PLN. Part of the study was conducted with the use of equipment purchased by the Medical University of Białystok as part of the RPOWP 20072013 funding, Priority I, Axis 1.1, contract No. UDARPPD.01.01.00-20-001/15-00 dated 26.06.2015.

\section{Conflict of interest}

The authors declare no conflict of interest.

\section{References}

1. AugerS, Ramarao N, FailleC, Fouet A, AymerichS, GoharM. Biofilm formation and cell surface properties among pathogenic and nonpathogenic strains of the Bacillus cereus group. Appl Environ Microbiol 2009; 75: 6616-6618.

2. Bottone EJ. Bacillus cereus, a volatile human pathogen. Clin Microbiol Rev 2010; 23: 382-398.

3. Sasahara T, Hayashi S, Morisawa Y, Sakihama T, Yoshimura A, Hirai Y. Bacillus cereus bacteremia outbreak due to contaminated hospital linens. Eur J Clin Microbiol Infect Dis 2011; 30: 219-226.

4. Thu N, Chau N, Thien L, Huy N, Khue N, Hung N, Luong NN, Thu LTA, Loc NH. Extrachromosomal expression of nat05 gene encoding an alkaline serine protease from Bacillus subtilis N05. BioTechnologia 2018; 99: 365-373.

5. Kandi V. Clinical significance of bacillus species other than Bacillus anthracis. J Med Microb Diagn 2016; 5: e130.

6. Aygun FD, Aygun F, Cam H. Successful treatment of Bacillus cereus bacteremia in a patient with propionic acidemia. Case Rep Pediatr 2016; 2016: 6380929.

7. Veysseyre F, Fourcade C, Lavigne JP, Sotto A. Bacillus cereus infection: 57 case patients and a literature review. Med Mal Infect 2015; 45: 436-440.

8. Glasset B, Herbin S, Granier SA, Cavalié L, Lafeuille E, Guérin $C$, Ruimy R, Casagrande-Magne F, Levast M, Chautemps N, Decousser JW, Belotti L, Pelloux I, Robert J, Brisabois A, Ramarao N. Bacillus cereus, a serious cause of nosocomial infections: epidemiologic and genetic survey. PLoS One 2018; 13: e0194346.

9. Sliman R, Rehm S, Shlaes DM. Serious infections caused by Bacillus species. Medicine (Baltimore) 1987; 66: 218-223.

10. Callegan MC, Kane ST, Cochran DC, Novosad B, Gilmore MS, Gominet M, Lereclus D. Bacillus endophthalmitis: roles of bacterial toxins and motility during infection. Invest Ophthalmol Vis Sci 2005; 46: 3233-3238.

11. Hemady R, Zaltas M, Paton B, Foster CS, Baker AS. Bacillus-induced endophthalmitis: new series of 10 cases and review of the literature. Br J Ophthalmol 1990; 74: 26-29.

12. Saleh F, Kheirandish F, Azizi H, Azizi M. Molecular diagnosis and characterization of Bacillus subtilis isolated from burn wound in Iran. Res Mol Med 2014; 2: 40-4.

13. Callewaert L, Michiels CW. Lysozymes in the animal kingdom. J Biosci 2010; 35: 127-160.

14. Ragland SA, Criss AK. From bacterial killing to immune modulation: recent insights into the functions of lysozyme. PLoS Pathog 2017; 13: e1006512. 
15. Leszczynska K, Namiot D, Byfield FJ, Cruz K, ZendzianPiotrowska M, Fein DE, Savage PB, Diamond S, McCulloch CA, Janmey PA, Bucki R. Antibacterial activity of the human host defence peptide LL-37 and selected synthetic cationic lipids against bacteria associated with oral and upper respiratory tract infections. J Antimicrob Chemother 2013; 68: 610-618.

16. Vila-Farrés X, Callarisa AE, Gu X, Savage PB, Giralt E, Vila J. CSA-131, a ceragenin active against colistin-resistant Acinetobacter baumannii and Pseudomonas aeruginosa clinical isolates. Int J Antimicrob Agents 2015; 46: 568-571.

17. Durnaś B, Piktel E, Watek M, Wollny T, Góźdź S, SmokKalwat J, Niemirowicz K, Savage PB, Bucki R. Anaerobic bacteria growth in the presence of cathelicidin LL-37 and selected ceragenins delivered as magnetic nanoparticles cargo. BMC Microbiol 2017; 17: 167.

18. Durnaś B, Wnorowska U, Pogoda K, Deptuła P, Wątek M, Piktel E, Głuszek S, Gu X, Savage PB, Niemirowicz K, Bucki R. Candidacidal activity of selected ceragenins and human cathelicidin LL-37 in experimental settings mimicking infection sites. PLoS One 2016; 11: e0157242.

19. Lara D, Feng Y, Bader J, Savage PB, Maldonado RA. Antitrypanosomatid activity of ceragenins. J Parasitol 2010; 96: 638-642

20. Howell MD, Streib JE, Kim BE, Lesley LJ, Dunlap AP, Geng D, Feng Y, Savage PB, Leung DYM. Ceragenins: a class of antiviral compounds to treat orthopox infections. J Invest Dermatol 2009; 129: 2668-2675.

21. Pollard J, Wright J, Feng Y, Geng D, Genberg C, Savage PB. Activities of ceragenin CSA-13 against established biofilms in an in vitro model of catheter decolonization. Antiinfect Agents Med Chem 2009; 8: 290-294.

22. Ding B, Guan Q, Walsh JP, Boswell JS, Winter TW, Winter ES, Boyd SS, Li C, Savage PB. Correlation of the antibacterial activities of cationic peptide antibiotics and cationic steroid antibiotics. J Med Chem 2002; 45: 663-669.

23. Piktel E, Pogoda K, Roman M, Niemirowicz K, Tokajuk G, Wróblewska M, Szynaka B, Kwiatek WM, Savage PB, Bucki R. Sporicidal activity of ceragenin CSA-13 against Bacillus subtilis. Sci Rep 2017; 7: 44452.

24. Ha JH, Ha SD. Synergistic effects of ethanol and UV radiation to reduce levels of selected foodborne pathogenic bacteria. J Food Prot 2010; 73: 556-561.

25. Wnorowska U, Niemirowicz K, Myint M, Diamond SL, Wróblewska M, Savage PB, Janmey PA, Bucki R. Bactericidal activities of cathelicidin LL-37 and select cationic lipids against the hypervirulent Pseudomonas aeruginosa strain LESB58. Antimicrob Agents Chemother 2015; 59: 3808-3815.

26. Bollenbach T. Antimicrobial interactions: mechanisms and implications for drug discovery and resistance evolution. Curr Opin Microbiol 2015; 27: 1-9.

27. Majewski K, Kozłowska E, Żelechowska P, BrzezińskaBłaszczyk E. Serum concentrations of antimicrobial peptide cathelicidin LL-37 in patients with bacterial lung infections. Centr Eur J Immunol 2018; 43: 453-457.

28. Błażewicz I, Jaśkiewicz M, Piechowicz L, Neubauer D, Nowicki R, Kamysz W, Barańska-Rybak W. Activity of antimicrobial peptides and conventional antibiotics against superantigen positive Staphylococcus aureus isolated from patients with atopic dermatitis. Adv Dermatol Allergol 2018; 35: 74-82.
29. Jeon YL, Yang JJ, Kim MJ, Lim G, Cho SY, Park TS, Suh JT, Park YH, Lee MS, Kim SC, Lee HJ. Combined Bacillus licheniformis and Bacillus subtilis infection in a patient with oesophageal perforation. J Med Microbiol 2012; 61: 1766-1769.

30. Chan WM, Liu DT, Chan CK, Chong KK, Lam DS. Infective endophthalmitis caused by Bacillus cereus after cataract extraction surgery. Clin Infect Dis 2003; 37: e31-e34.

31. Osman KM, Kappell AD, Orabi A, Al-Maary KS, Mubarak AS, Dawoud TM, Hemeg HA, Moussa IMI, Hessain AM, Yousef HMY, Hristova KR. Poultry and beef meat as potential seedbeds for antimicrobial resistant enterotoxigenic Bacillus species: a materializing epidemiological and potential severe health hazard. Sci Rep 2018; 8: 11600 .

32. Gao T, Ding Y, Wu Q, Wang J, Zhang J, Yu S, Yu P, Liu C, Kong L, Feng Z, Chen M, Wu S, Zeng H, Wu H. Prevalence, virulence genes, antimicrobial susceptibility, and genetic diversity of Bacillus cereus isolated from pasteurized milk in China. Front Microbiol 2018; 9: 533.

33. Chin JN, Jones RN, Sader HS, Savage PB, Rybak MJ. Potential synergy activity of the novel ceragenin, CSA-13, against clinical isolates of Pseudomonas aeruginosa, including multidrug-resistant P. aeruginosa. J Antimicrob Chemother 2008; 61: 365-370.

34. Epand RF, Pollard JE, Wright JO, Savage PB, Epand RM. Depolarization, bacterial membrane composition, and the antimicrobial action of ceragenins. Antimicrob Agents Chemother 2010; 54: 3708-3713.

35. Leszczyńska K, Namiot A, Cruz K, Byfield FJ, Won E, Mendez G, Sokołowski W, Savage PB, Bucki R, Janmey PA. Potential of ceragenin CSA-13 and its mixture with pluronic F-127 as treatment of topical bacterial infections. J Appl Microbiol 2011; 110: 229-238.

36. Dubois T, Guillard R, Prieels JP, Perraudin JP. Comparison between the folding of reduced hen egg white lysozyme and that of reduced human milk lysozyme. Biochemistry 1982; 21: 6516-6523.

37. Singh PK, Tack BF, McCray PB, Welsh MJ. Synergistic and additive killing by antimicrobial factors found in human airway surface liquid. Am J Physiol Lung Cell Mol Physiol 2000; 279: L799-L805.

38. Leszczyńska K, Namiot A, Janmey PA, Bucki R. Modulation of exogenous antibiotic activity by host cathelicidin LL-37. APMIS 2010; 118: 830-836.

39. Hashemi MM, Holden BS, Durnaś B, Bucki R, Savage PB. Ceragenins as mimics of endogenous antimicrobial peptides. J Antimicrob Agents 2017; 3: 141.

40. Long C, Liu B, Xu C, Jing Y, Yuan Z, Lin X. Causative organisms of post-traumatic endophthalmitis: a 20-year retrospective study. BMC Ophthalmol 2014; 14: 34

41. López-Cabezas C, Muner DS, Massa MR, Mensa Pueyo JM. Antibiotics in endophthalmitis: microbiological and pharmacokinetic considerations. Curr Clin Pharmacol 2010; 5: 47-54.

42. Bozkurt-Guzel C, Savage PB, Gerceker AA. In vitro activities of the novel ceragenin CSA-13, alone or in combination with colistin, tobramycin, and ciprofloxacin, against Pseudomonas aeruginosa strains isolated from cystic fibrosis patients. Chemotherapy 2011; 57: 505-510.

43. Bozkurt-Guzel C, Savage PB, Akcali A, Ozbek-Celik B. Potential synergy activity of the novel ceragenin, CSA-13, against carbapenem-resistant Acinetobacter baumannii 
strains isolated from bacteremia patients. Biomed Res Int 2014; 2014: 710273.

44. Cao D, Wu H, Li Q, Sun Y, Liu T, Fei J, Zhao Y, Wu S, $\mathrm{Hu} \mathrm{X}, \mathrm{Li}$ N. Expression of recombinant human lysozyme in egg whites of transgenic hens. PLoS One 2015; 10: e0118626.

\section{Address for correspondence:}

\section{Bonita Durnaś}

Department of Microbiology and Immunology

Faculty of Medicine and Health Sciences

Jan Kochanowski University

al. IX Wieków Kielc, 25-317 Kielce, Poland

Phone: +484136747 10

E-mail: Bonita.Durnas@onkol.kielce.pl 